\title{
Organizational Factors to the Effectiveness of Implementing Servitization Strategy
}

\author{
Zahir Ahamed, Akira Kamoshida, Takehiro Inohara \\ Graduate School of Decision Science and Technology, Tokyo Institute of Technology, Tokyo, Japan. \\ Email: zahir@valdes.titech.ac.jp
}

Received March $1^{\text {st }}, 2013$; revised April $3^{\text {rd }}, 2013$; accepted April 10 ${ }^{\text {th }}, 2013$

Copyright (C) 2013 Zahir Ahamed et al. This is an open access article distributed under the Creative Commons Attribution License, which permits unrestricted use, distribution, and reproduction in any medium, provided the original work is properly cited.

\begin{abstract}
It has been recognized that in today's highly competitive industrial markets, servitization is one of the key strategic choices for many leading manufacturers to gain differentiation from competitors by offering value-added services. To do so, however, requires a service-oriented strategy and the active implementation of this strategy, which comprises a significant shift in the underlying business model, management philosophy and approach. Unfortunately, there has no study examined the organization factors specific to the issues of servitization strategy. Therefore, this paper aims to examine the influence of organization factors on the effectiveness of implementing servitization strategy. Data was collected from three multinational electronics/ICT firms in Japan, respectively, Fujitsu, Toshiba, and Hitachi limited (FTH). Organization answer to a survey included multiple choices and open questions about the perception, process, barriers, and the important factors of implementing servitization strategy. The study result revealed that there were significantly positive influences of organizational factors, such as leadership $(17.2 \%)$, vision $(16.3 \%$, and marketing $(9.5 \%)$, on the effectiveness of implementing servitization strategy.
\end{abstract}

Keywords: Servitization; Service Design; Strategy Implementation; Organizational factors; Case Study

\section{Introduction}

Recently, it has been observed a significant trend in manufacturing industry that the firms are shifting their business from not only producing goods to offering an integrated package of goods and services. This movement has been termed as "servitization of business". The concept first introduced by Vandermerwe and Rada [1], is now widely recognized as the process of creating value by adding services to products. Since the late 1980 s, the adoption of this concept as a competitive business strategy of manufacturing firm has been studied by range of authors [2-5] who have highly focused on developing the process and its implications in product saturated market. This literature indicates a growing interest in this topic by academia, business and government [6], much of which is based on a belief that a move towards servitization is a means to create additional value adding capabilities for traditional manufacturers. As a result, today many leading companies embrace this concept as a service-led competitive strategy, environmental sustainability, and the basis to differentiate them from competitors who simply offer lower priced products.
Traditionally services provided by manufacturing organizations have typically been in the form of after-sales. Services such as installation, maintenance and repair have therefore generally been viewed as complementary to the primary business focus on selling products [7]. Hence, services have conventionally been considered as necessary add-ons to the core product portfolio. The more contemporary view is that manufacturing companies need to move towards a more extensive provision of services to remain its competitiveness in the current marketplace $[3,8,9]$. The rationale for developing service operations, extending the services business and integrating products and services can be summarized by following view points that drive companies to pursue a servitization strategy; namely, financial, strategic, economic, marketing and environments:

1) Financial Benefits: Services retain potentially higher margins than products [10-12], and generate substantial revenue from an installed base of products with a long life cycle $[13,14]$. However it secured the company for regular income and balances the effects of mature markets and unfavorable economic cycles $[15$, $16]$. 
2) Strategic Advantages: Service addition helps the firm differentiate from competition, aids the consolidation and protection of the core product businesses, and establishes intimate relationships with clients. Since services are more labor dependent and less visible rendering them more difficult to imitate, and hence a source of sustainable competitive advantage [3,9].

3) Economic Pressure: Service roles in manufacturing sector are growing rapidly, as increased the share of services activities are necessary to produce goods [17, 18]. Also, the de-industrialization and increasing international division of labor between manufacturing and services led to the declining shares of manufacturing in developed economies.

4) Marketing Opportunities: Service component has great influence on purchasing decision and tend to induce repeat-sales, and by intensifying contact opportunities with the customer, can put the supplier in the right position to offer other products or services $[16$, 19].

5) Environmental Rationale: Services make sure the use of resources more rationally and proper way [20].

Thus, by offering services, companies can gain insight into their customers' needs and are able to develop more tailored offerings which in long-run creates values for organizations. It has been observed in successful cases that organizations such as IBM, General Electric, Fujitsu, Siemens, Cannon and Hitachi have had a significant share of revenues and profits from services since they transformed into services operation in mid 1990s or/and in the early millenniums. Oliva and Kallenberg [3], Araujo and Spring [10] and Davies [21] argue that during this transformation to a combined product-service offering, organizations are likely to change their strategies, operations and value chains, technologies, people expertise and system integration capabilities. However, the transformation paths from product-centric strategy to a combined product-service strategy are still poorly understood and remain a new and complex concept $[12,22,23]$. Hence, the purpose of this paper is to seek the influence of organizational factors experienced by Japanese manufacturing firms toward an implementing servitization strategy.

In this study we aimed at exploring the tendency of Japanese electronic/ICT firms toward servitization, and identifying factors that influence to the effectiveness of implementing servitization strategy. The main study materials were gathered with the help of questionnaire, discussion, and observations of three giant electronics/ICT companies in Japan, namely, Fujitsu, Toshiba, and Hitachi limited (FTH). The structure of this paper is as follows: after this introduction section research background and hypothesis is presented. Section 3 describes the research methodology was used in this paper. This is fol- lowed by Section 4, which verifies and analyzes the factors that influence on implementing servitization strategy by using path analysis. The next section we articulate the output of the results and presented the degree of influence toward servitization strategy. Section 6 concludes the paper with summary and gives suggestions for the future research in the field of servitization of business.

\section{Towards Servitization of Business}

\subsection{Background}

Today, manufacturing industries, especially high-tech firms are under massive pressure and realize the difficulties to achieve their desired profit from only selling goods, which forces them to respond by moving up value chain, seeking to innovate and create more sophisticated products and services so that they do not have to compete on the basis of cost alone [24]. In these circumstances, the concept of servitization becomes an increasingly relevant strategy for manufacturing firms in developed economies to improve their competitive advantage in the market. Many manufacturers offer services, but may not use services as the basis of their competitive strategy. Servitization is defined as the strategic innovation of organization's capabilities and processes to shift from selling products to selling an integrated product and service offering that delivers value in use $[1,25]$. There are various forms of servitization such as the Tukker [22] proposes. They range from products with services as an "add-on", to services with tangible goods. They tend to be delivered using customer-centric strategies in order to provide "desired outcomes for the customer. According to Oliva and Kallenberg [3], customer orientation consists of two distinctive elements; first, a shift of the service offering from product-oriented service to "user's process oriented services" (i.e., a shift from a focus on ensuring the proper functioning and/or customer's use of the product to pursuing efficiency and effectiveness of end-user's processes related to the product), and second, a shift of the nature of the customer interaction from transaction-based to relationship-based (i.e., a shift from selling products to establishing and maintaining a relationship with the customer). In other words, both a transfer from the old transaction-based mode of service to continuous connection with the customer and a shift towards process-oriented services for end-users instead of physical goods efficacy is required.

Servitization frequently occurs as a response to financial difficulties, new customer demands and strategic product differentiation $[3,9,19]$. But, it is not an easy strategic choice that a manufacturer needs to carefully design its services. In order to succeed with servitization, manufacturer is likely to need some new and alternative 
organizational principles, structures, and processes. Wise and Baumgartner [2], Oliva and Kallenberg [3] and Weeks [25] claimed that to implement a servitization strategy successfully, organizations are required to change their strategies, operations and value chains, technologies, peoples for supporting cultural shifts in the organizational blueprint, and system integration capabilities. However, commentators have also suggested that companies need to maintain a constant flow of innovation, not only in terms of what is offered to the customer, but also in how products and services are designed, produced, delivered, and marketed [26,27]. Based on the previous studies, it is observed that while there is a significant literature, theoretical models, and discussions available in the general field of organizational success factors, there are no models or study related to the specific issues of organizational success toward implementing servitization strategy. Thus, this research is trying to identify the influential factors of organization, which has significantly positive impact on implementing servitization strategy.

\subsection{Hypothesis}

This research hypothesizes that the implementing servitization strategy required a collaborative support of many organizational forces, which is implicitly or explicitly influence on building firm product-service operations or along with the change of company's new directions. Based on a comprehensive list of organizational factors from related studies [28-34], five organizational factors that influence on implementing servitization strategy are identified to use in this study. The five factors are vision, organization, human resource, leadership, and marketing as shown in Figure 1.

Based on the review of the literature on the five dimension related to the implementation of servitization strategy, the following hypotheses are presented:

H1: Vision has a significantly positive influence on implementing servitization strategy.

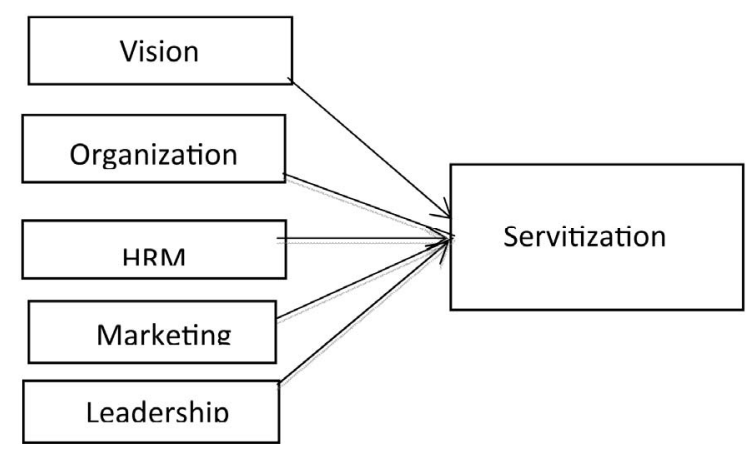

Figure 1. Structural model exploring the influence of organizational vision, organization, human resource, leadership, and marketing on implementing servitization strategy.
$\mathrm{H} 2$ : Organization has a significantly positive influence on implementing servitization strategy.

H3: Human resources have significantly positive influence on implementing servitization strategy.

H4: Marketing has a significantly positive influence on implementing servitization strategy.

H5: Leadership has a significantly positive influence on implementing servitization strategy.

\section{Methodology}

\subsection{Data Collection}

A self-administered questionnaire was used to measure the factors under the investigation. Prior to the actual distribution of the questionnaire, a discussions and pilot study were conducted with the engagement of the firm over two months period. This helps the authors to explain the objective of questionnaire to the respondents and ensure the consistency and clarity of the questions asked which resulted in the questionnaires being refined and rephrased accordingly. The questionnaires were also translated to the native language (Japanese Language) for better understanding who were less expert in English.

The questionnaires were then distributed to the employees of three multinational Japanese electronic/ICT firms, referred to as Fujitsu, Toshiba, and Hitachi (FTH), which can be qualified in its industry as a medium or large size companies with yearly sales of JPY 4467 billion, 6100 billion, and 9665 billion (FY 2012) respectively [35-37]. The selection of these companies were a critical task for this study, as we sought to investigate the hi-tech manufacturing firms who have a track record of successful provision of product related services. For this reason, we have adopted a purposive sampling strategy and selected Japan based original hi-technology products manufacturer that designs and manufactures high-value electronics/IT goods for the business enterprise, government and consumer market as well. A significant trend of these three companies movement toward servitization of business is explained in the following as case 1 (Fujitsu), case 2 (Toshiba), and case 3 (Hitachi):

Case 1: Fujitsu limited, a leading Japanese information and communication technology (ICT) firm was established in 1935, as the manufacturing subsidiary of Fuji Electric limited. At the beginning of the journey, company started to produce telephone and automotive exchange equipment and steadily expanded its activities in producing computers, semiconductors, and telecommunications equipment and so on. Historically, Fujitsu was best known as the world's number 2 maker of mainframe computers, just behind IBM, but they exited from that market at the turn of the millennium to focus its hardware efforts on Unix-based servers, personal computers, and peripherals. In the early $21^{\text {st }}$ century, however, the firm was deemphasizing its hardware roots, billing itself 
as an internet-centered company, and generating increasing amounts of revenues from services and software. The later, which included such areas as system integration services, front-end technologies, outsourcing services, network services, system support services, security solutions and consulting services. As a result, they achieved over 50 percent of revenues from the provision of services that are closely coupled to its products. The company has made a significant progress and is at a relatively advanced stage of servitization for a traditional manufacturer. This was confirmed by the portfolio strategy and marketing president who acknowledged that, "at the interfaces between the company and customers, I think we are now seeing far more evidence of responsive agile service-centered behavior and solution oriented to the customers, so that, today we recognized as the Japan's number 1 and world's $3^{\text {rd }}$ largest IT service provider in the industry".

Case 2: Toshiba, a world leader in high technology, is a diversified Japanese manufacturer and marketer of advanced electronic and electrical products, spanning information \& communications equipment and systems, internet-based solutions and services, electronic components and materials, power systems, industrial and social infrastructure systems, and household appliances. Under the management vision of "Innovation-driven, customerfocused growth", the key objective of the Toshiba is to provide total utmost satisfaction to customers worldwide through leading-edge products and top-of-the-line services. In realizing this objective, company started to transform its business structure from not only productcentric to product-service-centric organization and strengthening such focus businesses as integrated storage solutions, retail solutions, home solutions, health care services and solutions, and so on. In order to offer these wide ranges of solutions to such business, pursuing technology development, Toshiba realizing the importance of M\&A investments and established new business alliances. In addition, the firm continuing speed up the pace of innovation by nurturing the buds for next generation business development and creating exciting new values through the introduction of World's First and expansion of World's No.1 products and services in the global market.

Case 3: Hitachi is a traditional manufacturing firm often called the General Electric of Japan, and is in fact considered to be one of the "Big Five" sogo denki or general electric companies in Japan. The company balanced its portfolio of business activities predominantly in the field of electronics and electrical engineering that renowned the Hitachi as a giant manufacturer in the industry. However, in the middle part of the last decade, company realizes a significant change in the market demand, increasing customer expectations for reliable and high quality services, cutthroat competition, and a thin profit margin of manufacturing goods that calculated only $2 \%$ of total revenues compared to more than $7 \%$ from maintenance services. In these circumstances, Hitachi started to shift its operations from not only producing or selling goods to offering an integrated package of goods and services, even they already had hardware depend services approximately 30 years ago like, maintenances. So, in extend to service provision with core business, company added non-hardware (Service ware) depend services including operation management systems, staffing, training, consulting, and solutions, etc. and expected to gain $7 \%$ to $8 \%$ profit from combination of goods and services (Senior marketing manager). Of particular interest is the way in which the company is frequently held to be an exemplar of the trend towards servitization of business [21,38,39].

The questionnaire for this study consisted of 30 items, there were 25 items divided into five dimensions based on the literature review as mentioned before and other 5 items were about the questions of servitization strategy. A total of 100 questionnaires were distributed, and 57 were returned giving a response rate of $57 \%$. The respondents' background ranges from diverse functional areas including, planning and decision making, research and development, portfolio strategy and marketing unit, finance and human resource, business development unit, service design and engineering and so on. The majority of the respondents $(70 \%)$ occupy managerial rank or higher-level positions. The proportion in this rank includes HR managers, sales and marketing managers, service engineers, operational managers, ubiquitous managers and senior managers. The other $30 \%$ of the respondents belong to the top-level management. They are the marketing directors, vice president of portfolio strategy, senior consultants, and CEO. The use of respondents from different backgrounds allowed different avenues of inquiry to be pursued in the data collection [40]. The questionnaire focused on determining the influence organizational factors on implementing servitization strategy. Subjects were asked to assess their perceptions of various items of different constructs about the factors of organization and servitization strategy. Assessment were based on a five-point Likert scale ranging from $1=$ strongly disagreed to $5=$ strongly agreed the participants indicated to what degree they observed the reasons as important. Measures were adapted from [41].

\subsection{Data Analysis and Procedure}

The research model was analyzed using SPSS 18.0 program (PASW). In order to ensure that the variables were internally consistent, reliability assessment was carried out using Cronbach's Alpha (Table 1). The results showed that the value of Cronbach's Alpha for all vari- 
ables is higher than 0.8 , satisfying a minimum requirement of 0.6. This suggests that the questionnaire and its variables are reliable for the intended study.

According to the above Table 1, it is clear that we can use all variables for the further statistical analysis, i.e., path analysis, which we conduct in Section 4.

\section{Path Analysis}

To verify the influence of organizational factors on implementing servitization strategy, a path model linking vision $(V)$, organization $(O)$, human resource management $(H)$, marketing $(M)$, and leadership $(L)$ with servitization $(S)$ is tested using a series of regression analysis in SPSS (PASW 18.0). The following path diagram in Figure 2 is representing a proposed hypothetical model involving five variables.

Figure 2 indicates that the path diagram consists of a substructure, which contains five exogenous variables $V$, $O, H, M, L$ and an endogenous variable $S$. Therefore, the structural equation from above path diagram is as follows:

$$
S=\rho_{S V} V+\rho_{S O} O+\rho_{S H} H+\rho_{S M} M+\rho_{S L} L+\varepsilon .
$$

According to the structural equation, servitization is influenced by five exogenous variables $V, O, H, M$, and $L$. We will investigate how these variables $V, O, H, M$, and $L$ are influenced to the implementation of servitization strategy.

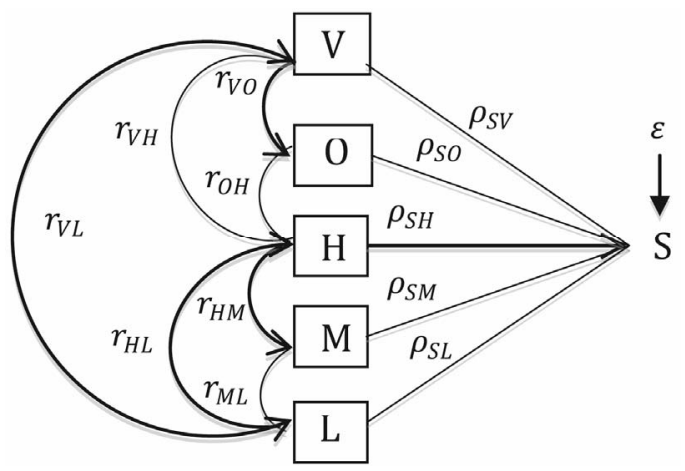

Figure 2. Structural relationship between $V, O, H, M, L$ and $S$.

Table 1. Reliability test results of the independent variables.

\begin{tabular}{ccc}
\hline Variables & Items & Cronbach's Alpha \\
\hline Vision & 5 & 0.899 \\
Organization & 5 & 0.897 \\
HRM & 5 & 0.898 \\
Marketing & 5 & 0.896 \\
Leadership & 5 & 0.898 \\
\hline
\end{tabular}

\subsection{Correlations}

First, we investigate the correlations of each variable $V$, $O, H, M$, and $L$ to $S$. Based on the data, the correlations matrix between variables has been obtained by using SPSS version 18.0 (PASW). The output of the result is shown in Table 2.

Based on Table 2, for example, the correlation between organization and servitization is 0.379 . From Table 2, the variable which have high correlation is vision, i.e., 0.638 .

\subsection{Regression}

Here are the tests for the predictors' goodness of the fit of the regression model and regression equation.

In Table 3, the $R^{2}$ is 0.577 . This suggests that there is $57.7 \%$ goodness of fit of the model produced by the regression equation. From $R^{2}$, we can calculate the path coefficient for others variable, which is not included in our model. Thus, $\rho_{S \varepsilon}=\sqrt{1-0.577}=0.650$.

In Table 4, ANOVA tested the hypothesis that there is a linear relationship between the predictors and the dependent variable. $F$ is the ratio of the mean square for regression to the mean square for the residual. In Table 3, when all predictors were entered, the significance level

Table 2. Correlations between variables.

\begin{tabular}{|c|c|c|c|c|c|c|c|}
\hline & & $S$ & $V$ & $O$ & $H$ & $M$ & $L$ \\
\hline \multirow{3}{*}{$S$} & $\begin{array}{c}\text { Pearson } \\
\text { Correlation }\end{array}$ & 1 & 0.638 & 0.379 & 0.383 & 0.547 & 0.629 \\
\hline & Sig. (1-tailed) & & 0.000 & 0.002 & 0.002 & 0.000 & 0.000 \\
\hline & $\mathrm{N}$ & 57 & 57 & 57 & 57 & 57 & 57 \\
\hline \multirow{3}{*}{$V$} & $\begin{array}{c}\text { Pearson } \\
\text { Correlation }\end{array}$ & 0.638 & 1 & 0.451 & 0.299 & 0.437 & 0.532 \\
\hline & Sig. (1-tailed) & 0.000 & & 0.000 & 0.012 & 0.000 & 0.000 \\
\hline & $\mathrm{N}$ & 57 & 57 & 57 & 57 & 57 & 57 \\
\hline \multirow{3}{*}{$O$} & $\begin{array}{c}\text { Pearson } \\
\text { Correlation }\end{array}$ & 0.379 & 0.451 & 1 & 0.416 & 0.353 & 0.348 \\
\hline & Sig. (1-tailed) & 0.002 & 0.000 & & 0.001 & 0.004 & 0.004 \\
\hline & $\mathrm{N}$ & 57 & 57 & 57 & 57 & 57 & 57 \\
\hline \multirow{3}{*}{$H$} & $\begin{array}{c}\text { Pearson } \\
\text { Correlation }\end{array}$ & 0.383 & 0.299 & 0.416 & 1 & 0.277 & 0.381 \\
\hline & Sig. (1-tailed) & 0.002 & 0.012 & 0.001 & & 0.018 & 0.002 \\
\hline & $\mathrm{N}$ & 57 & 57 & 57 & 57 & 57 & 57 \\
\hline \multirow{3}{*}{$M$} & $\begin{array}{c}\text { Pearson } \\
\text { Correlation }\end{array}$ & 0.547 & 0.437 & 0.353 & 0.277 & 1 & 0.445 \\
\hline & Sig. (1-tailed) & 0.000 & 0.000 & 0.004 & 0.018 & & 0.000 \\
\hline & $\mathrm{N}$ & 57 & 57 & 57 & 57 & 57 & 57 \\
\hline \multirow{3}{*}{$L$} & $\begin{array}{c}\text { Pearson } \\
\text { Correlation }\end{array}$ & 0.629 & 0.532 & 0.348 & 0.381 & 0.445 & 1 \\
\hline & Sig. (1-tailed) & 0.000 & 0.000 & 0.004 & 0.002 & 0.000 & \\
\hline & $\mathrm{N}$ & 57 & 57 & 57 & 57 & 57 & 57 \\
\hline
\end{tabular}


associated with the observed value of $F$ was 13.909 $(=0.000)$. Thus, the hypothesis can be accepted and we may conclude that there is a significant linear relationship between the set of independent variables and the dependent variable.

In Table 5, coefficients for variables $V$ to $L$ or beta coefficients has been calculated, i.e., $\rho_{S V}$ is 0.347 ; $\rho_{S O}$ is $-0.008 ; \rho_{S H}$ is $0.102 ; \rho_{S M}$ is 0.235 ; and $\rho_{S L}$ is 0.304 . Therefore, the regression coefficients from the above results can be represented in our output path diagram in Figure 3. Here, we also displayed the $r_{V O}, r_{O H}$, $r_{H M}, r_{M L}, r_{V H}, r_{H L}$, and $r_{V L}$ values of $R^{2}$.

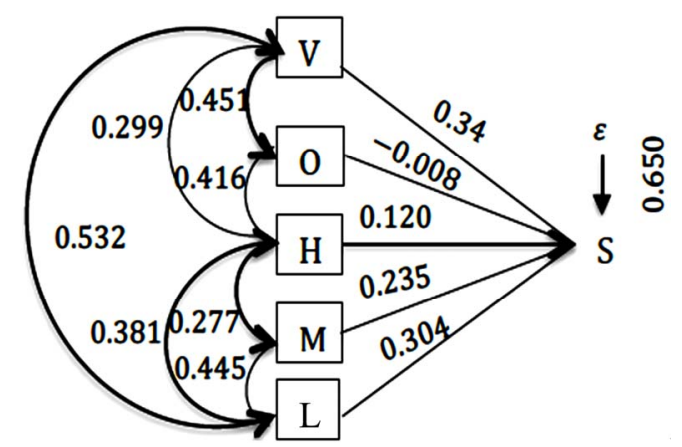

Figure 3. Output path diagram (Structural relationship of $V$, $O, H, M$ and $L$ to $S$ ).

Table 3.Summary of the model testing.

\begin{tabular}{ccccc}
\hline Model & $\mathrm{R}$ & R Square & $\begin{array}{c}\text { Adjusted R } \\
\text { Square }\end{array}$ & $\begin{array}{c}\text { Std. Error of } \\
\text { the Estimate }\end{array}$ \\
\hline 1 & $0.760^{\mathrm{a}}$ & 0.577 & 0.535 & 0.361 \\
\hline
\end{tabular}

a Predictors: (Constant), V, O, H, M, L.

Table 4. ANOVA output of the hypothesis testing.

\begin{tabular}{lcccccc}
\hline & Model & $\begin{array}{c}\text { Sum of } \\
\text { Squares }\end{array}$ & df & $\begin{array}{c}\text { Mean } \\
\text { Square }\end{array}$ & F & Sig. \\
\hline 1 & Regression & 9.100 & 5 & 1.820 & 13.909 & $0.000^{\mathrm{a}}$ \\
& Residual & 6.673 & 51 & 0.131 & & \\
\hline
\end{tabular}

${ }^{\mathrm{a}}$ Predictors: (Constant), $V, O, H, M, L$.

Table 5. Regression coefficients analysis.

\begin{tabular}{|c|c|c|c|c|c|c|}
\hline & \multirow[t]{2}{*}{ Model } & \multicolumn{2}{|c|}{$\begin{array}{l}\text { Unstandardized } \\
\text { Coefficients }\end{array}$} & \multirow{3}{*}{$\begin{array}{c}\begin{array}{c}\text { Standardized } \\
\text { Coefficients }\end{array} \\
\text { Beta }\end{array}$} & \multirow[t]{2}{*}{$\mathrm{t}$} & \multirow[t]{2}{*}{ Sig. } \\
\hline & & B & Std. Error & & & \\
\hline \multirow{6}{*}{1} & (Constant) & 0.353 & 0.405 & & 0.870 & 0.388 \\
\hline & $L$ & 0.276 & 0.105 & 0.304 & 20.635 & 0.011 \\
\hline & $V$ & 0.358 & 0.120 & 0.347 & 20.977 & 0.004 \\
\hline & $M$ & 0.208 & 0.095 & 0.235 & 20.191 & 0.033 \\
\hline & $O$ & -0.007 & 0.100 & -0.008 & -0.071 & 0.944 \\
\hline & $H$ & 0.068 & 0.070 & 0.102 & 0.973 & 0.335 \\
\hline
\end{tabular}

\section{Output of the Results}

\subsection{Identifying Influential Factors}

The relevant output is in the tables labeled Correlations, Model Summary, ANOVA and Coefficients. These tables are shown in SPSS output 18.0 (PASW). The first table in the output (not produced here) gives descriptive statistics such as means and standard deviations. Next comes the correlations table, and we see that the correlations that our model specified as casual effects are all statistically significant. This is encouraging. The next table (not produced here) is Variables Entered/Removed, and this just tells us that vision, organization, HRM, marketing, and leadership were entered properly and that servitization was the dependent variable. Next is the model summary, in which we see that $R^{2}=0.577$. Thus, there is $57.7 \%$ goodness of fit of the model produced by the regression equation. Then comes an ANOVA table that just confirms that the regression equation is significant. Finally, we have the coefficients table, in which we see that the "Sig." values are 0.004 for vision, 0.033 for marketing, and 0.011 for leadership to servitization, which is just significant $(p=0.05)$, as "Sig." $(p$-value $=0.05)$ is the significance level for the test of the hypothesis. But, the "Sig." value for factors, like organization and HRM are 0.944 and 0.335 respectively, which is greater than 0.05 and is not significant to servitization. Therefore, in Table 6, the hypothesis H1, H4, and H5 are accepted and have direct influence to the implementation of servitization strategy. But, the hypothesis $\mathrm{H} 2$ and $\mathrm{H} 3$ that there are a linear relationship between these predictors and attractiveness can be rejected.

\subsection{Degree of Influences (Proposition)}

According to the output of analysis described in the previous section, we found that the factors, like vision, marketing, and leadership are significantly influence to the implementation of servitization strategy. On the basis of this understanding, we can propose and improve the following path diagram involving three variables in Figure 4.

The current path diagram (Figure 4) contains three exogenous variables $V, M, L$ and an endogenous variable

Table 6. Result for hypotheses test.

\begin{tabular}{cl}
\hline Research Hypotheses & Results \\
\hline $1 \mathrm{H}$ & Accepted \\
$2 \mathrm{H}$ & Rejected \\
$3 \mathrm{H}$ & Rejected \\
$4 \mathrm{H}$ & Accepted \\
$5 \mathrm{H}$ & Accepted \\
\hline
\end{tabular}


$S$. Thus, the structural equation of this path diagram is as follows:

$$
S=\rho_{S V} V+\rho_{S M} M+\rho_{S L} L+\varepsilon .
$$

Based on the above structural equation, servitization is influenced by three exogenous variables $V, M$, and $L$. We will investigate how these variables $V, M$, and $L$ are influenced to the implementation of servitization strategy. The regression analyses required by the path model in this part are carried out in the same way, using regression dialog boxes. This time, we will not reproduce the output tables again, but only the relevant information from them is as follows: the correlations specified in the model are significant, the independent variables in each regression was entered and the ANOVA confirmed that all were significant. The $R^{2}$ is 0.569 , which means that there is $56.9 \%$ goodness of fit of the model produced by equation. Finally, the coefficients of the variables, in which $p$-value (Sig. column) $=0.002$ for vision, 0.023 for marketing, and 0.004 for leadership that are smaller than 0.05 and significant to the implementation of servitization strategy. The graphical regression coefficients are displayed in our output path diagram in Figure 5, where we also displayed the $r_{v m}, r_{m l}$, and $r_{v l}$ values of $R^{2}$. From $R^{2}$, we can calculate the path coefficient for others variable, which is not included in our model, i.e., $\rho_{S \varepsilon}=\sqrt{1-0.569}=0.656$.

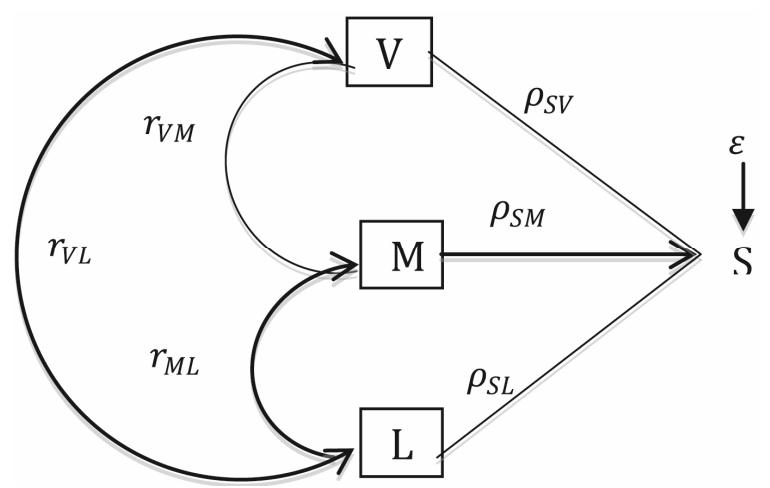

Figure 4. Structural relationship between $V, M, L$ and $S$.

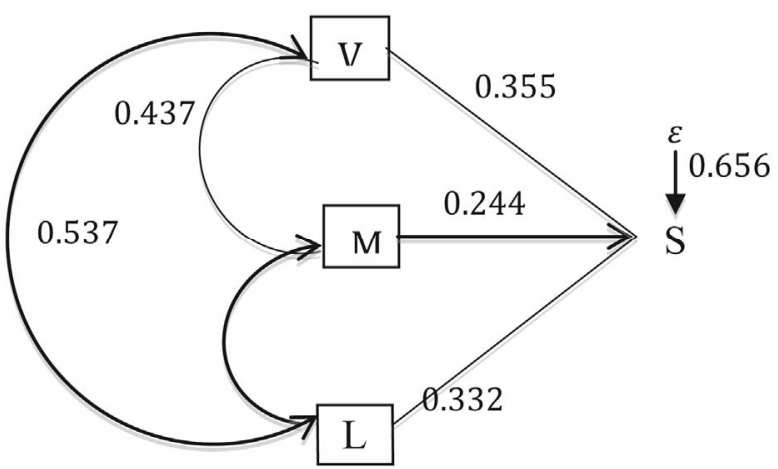

Figure 5. Output path diagram (Structural relationship of $V$, $M$, and $L$ to $S$ ).
In order to identify the degree of influence of variables $V, M$, and $L$ towards servitization, we calculated each of these variables' direct and correlative relational influences, which are as follows:

\section{1) Influence of Vision $(V)$}

Direct Influence

$$
=\rho_{S V} \times \rho_{S V}=(0.355)(0.355)=0.126
$$

Influence through correlative relations with marketing $(M)=\rho_{S V} \times r_{v m} \times \rho_{S m}=(0.355)(0.437)(0.244)=0.037$

\section{2) Influence of Marketing ( $M$ )}

Direct Influence

$$
=\rho_{S m} \times \rho_{S m}=(0.244)(0.244)=0.059
$$

(L)

Influence through correlative relations with leadership

$$
=\rho_{S m} \times r_{m l} \times \rho_{s l}=(0.244)(0.445)(0.332)=0.036
$$

\section{3) Influence of Leadership $(L)$}

Direct Influence

$$
=\rho_{s l} \times \rho_{s l}=(0.332)(0.332)=0.110
$$

Influence through correlative relations with vision

$$
(V)=\rho_{s l} \times r_{l v} \times \rho_{S V}=(0.332)(0.532)(0.355)=0.062
$$

Therefore, on the basis of above calculations, we can summarize the following results:

1) The direct influence of vision $(V)$ toservitization is $12.6 \%(0.126)$, and through the relationship with marketing is $3.7 \%(0.037)$. Thus, the influence of vision toward implementing servitization strategy in total is $16.3 \%(0.163)$.

2) The direct influence of marketing $(M)$ to servitization is $5.9 \%(0.059)$, and through the relationship with leadership is $3.6 \%(0.036)$. Thus, the influence of marketing toward implementing servitization strategy in total is $9.5 \%(0.095)$.

3) The direct influence of leadership $(L)$ to servitization is $11 \%(0.110)$, and through the relationship with vision is $6.2 \%(0.062)$. Thus, the influence of leadership toward implementing servitization strategy in total is $17.2 \%(0.172)$.

\section{Conclusions}

Servitization is now widely recognized as the innovation of an organization's capabilities and processes, to better create value through a shift from selling product to selling product-service systems (PSS). To be competitive, sustainable, and differentiate itself, it is one of the key strategic choices that the manufacturers can consider for long run business perspectives. Today, many Japanese 
leading companies like, Fujitsu, Toshiba, Hitachi, and so on embraces this concept as a service-led competitive strategy, environmental sustainability, and the basis to differentiate themselves from competitors who simply offer lower priced products. But, transforming from product manufacturing to product-service system is not an easy strategic choice and that a manufacturer first needs to carefully design its services. To succeed with servitization, a manufacturer is likely to need some new and alternative organizational principles structures and processes. Consequently, the firm needs to understand the success factors, which is undoubtedly important towards implementing servitization strategy.

In this paper, the researcher explored the relationship between organizational five factors and the implementation of servitization strategy using a questionnaire survey of three Japanese electronics/ICT firms (FTH). The results of this study provide a clear indication that organizational factors are, indeed, highly significant on implementing servitization strategy. Our empirical study also found that organizational factors such as leadership $(17.2 \%)$, vision $(16.3 \%)$, and marketing $(9.5 \%)$ significantly influenced to the implementation of servitization strategy. The research result can be used to identify the key organizational factors in shifting from manufacturing to servitization, and to help companies for mitigating transition risks especially related to organizational process and behaviors. The expected benefits from this research are to help enterprise managers and decision makers to make the correct tactics for implementing servitization strategy and achieving their desired objectives. Since our empirical study analyzed data collected from 3 organizations in Japan, it would be interesting and valuable to conduct similar surveys in other regions for comparative studies. Furthermore, we may extend our study in the future by increasing the number of sampled companies, including other organizational factors such as organizational culture and top management support, management style, resources allocation, and investigating how the effectiveness of servitization strategy influences organizations upon their performance in various areas such as financial output, competition edge, customer satisfaction, corporate image, credibility, trust, and reputation in the market. Is there any other alternative that the manufacturer can consider as the value proposition to their offerings rather than servitization?

\section{REFERENCES}

[1] S. Vandermerwe, and J. Rada, "Servitization of Business: Adding Value by Adding Services," European Management Journal, Vol. 6, No. 4, 1988, pp. 314-324. doi:10.1016/0263-2373(88)90033-3

[2] R. Wise and P. Baumgartner, "Go Downstream: The New Profit Imperative in Manufacturing," Harvard Business
Review, Vol. 77, No. 5, 1999, pp. 133-141.

[3] R. Oliva and R. Kallenberg, "Managing the Transition from Products to Services," International Journal of Service Industry Management, Vol. 14, No. 2, 2003, pp. 160172. doi:10.1108/09564230310474138

[4] N. Slack, "Operations Strategy: Will Is Ever Realize Its Potential," Gestao \& Producao, Vol. 12, No. 3, 2005, pp. 323-332. doi:10.1590/S0104-530X2005000300004

[5] A. Neely, "The Servitization of Manufacturing: An Analysis of Global Trends," Centre for Business Performance, Cranfield School of Management, 2009.

[6] P. Hewitt, "The Government's Manufacturing Strategy," Secretary of State for Trade and Industry, 2000. wwwdti.gov.uk/manufacturing

[7] D. Bowen, C. Siehl and B. Schneider, "Developing Service-Oriented Manufacturing," In: I. Kilmann, Ed., Making Organizations Competitive, Jossey-Bass, San Francisco, 1991, pp. 397-418.

[8] N. W. Foote, J. Galbraith, Q. Hope and D. Miller, "Making Solutions the Answer," The MicKinesy Quarterly, Vol. 3, No. 1, 2001, pp. 84-93.

[9] H. Gebauer and T. Friedli and E. Fleisch, "Success Factors for Achieving High Service Revenues in Manufacturing Companies," Benchmarking: An International Journal, Vol. 13, No. 3, 2006, pp. 374-386. doi: $10.1108 / 14635770610668848$

[10] L. Araujo and M. Spring, "Service, Product, and the Institutional Structure of Production," Industrial Marketing Management, Vol. 35, No. 7, 2006, pp. 797-805. doi:10.1016/j.indmarman.2006.05.013

[11] VDMA, "Dien und Verdienen," VDMA Verlag, Frankfurt, 1998.

[12] R. Johnston, "The Determinants of Service Quality: Satisfiers and Dissatisfiers," International Journal of Service Industry Management, Vol. 6, No. 5, 1995, pp. 53-71. doi:10.1108/09564239510101536

[13] T. Knecht, R. Leszinski and F. Weber, "Memo to a CEO," The McKinsey Quarterly, Vol. 4, No. 1, 1993, pp. 79-86.

[14] G. W. Potts, "Exploiting Your Product's Service Life Cycle," Harvard Business Review, Vol. 66, No. 5, 1988, pp. 32-35.

[15] S. Brax, "A Manufacturer Becoming Service ProviderChallenges and Paradox," Manufacturing Service Quality, Vol. 15, No. 2, 2005, pp. 142-155.

[16] V. Malleret, "Value Creation through Service Offers," European Management Journal, Vol. 24, No. 1, 2006, pp. 106-116. doi:10.1016/j.emj.2005.12.012

[17] A. Wolfl, "Interactions between Services and Manufacturing-Findings from I-O and Occupations Data," OECD Workshop on Services, Paris, 15-16 November 2004.

[18] G. Ren and M. Gregory, "Servitizatin in Manufacturing Companies," Paper Presented at 16th Frontiers in Service Conference, San Francisco, 2007.

[19] H. Mathe and R. Shapiro, "Integrating Service Strategy in the Manufacturing Company," Chapman and Hall, London, 1993.

[20] O. Mont, "Product Service Systems," Final Report for 
IIIEE, Lund University, Lund, 2000.

[21] A. Davies, "Moving Base into High Value Integrated Solutions: A Value Stream Approach," Industrial and Corporate Change, Vol. 13, No. 5, 2004, pp. 727-756. doi:10.1093/icc/dth029

[22] A. Tukker, "Eight Types of Product-Service Systems: Eight Ways to Sustainability? Experiences from SusProNet," Business Strategy and the Environment, Vol. 13, No. 4, 2004, pp. 246-260. doi:10.1002/bse.414

[23] C. A. Voss, "Alternative Paradigms for Manufacturing Strategy," International Journal of Operations \& Production Management, Vol. 25, No. 2, 2005, pp. 314-324.

[24] M. Porter and C. Ketels, "UK Competitiveness: Moving to the Next Stage," Department of Trade and Industry, London, 2003.

[25] R. Weeks, "The Culture and Skills Challenges Associated with Servitization: A South African Persceptive," Graduate School of Technology Management, University of Pretoria, 2010.

[26] L. L. Berry, "Relationship Marketing of Services: Growing Interest, Emerging Perspectives," Journal of the Academy of Marketing Science, Vol. 23, No. 4, 1995, pp. 236245. doi: $10.1177 / 009207039502300402$

[27] C. Martin and D. Horne, "Restructuring towards a Service Orientation," International Journal of Service Industry Management, Vol. 3, No. 1, 1992, pp. 25-38.

[28] T. O. Davenport, "Human Capital: What Is and Why People Invest It,” Jossey-Bass, San Francisco, 1999.

[29] T. P. Flannery, D. A. Hofrichter and P. E. Platten, "People, Performance, and Pay: Dynamic Compensation for Changing Organizations," Free Press, New York, 1996.

[30] T. B. Weisis and F. Hartle, "Reengineering Performance Management: Breakthrough in Achieving Strategy through People," St. Luis Press, Boca Raton, 1997.

[31] J. R. Katzenbatch and D. K. Smith, "The Wisdom of Teams: Creating High-Performance Organizations," Har- vard Business School Press, Boston, 1993.

[32] J. M. Kouzes, and B. Z. Posner, "The Leadership Challenge: How to Get Extraordinary Things Done in Organizations," Jossey-Bass, San Francisco, 1987.

[33] B. George, "Authentic Leadership: Rediscovering the Secrets to Creating Lasting Value," Jossesy-Bass, San Francisco, 2003.

[34] W. B. Rouse, "A Theory of Enterprise Transformation," Wiley InterScience, Hoboken, 2005, pp. 279-295.

[35] "Fujitsu Annual Report 2012," 2012. http://www.fujitsu.com/downloads/IR/annual/2012/all.pdf

[36] “Toshiba Annual Report 2012,” 2012. http://www.toshiba.co.jp/about/ir/en/finance/ar/ar2012/tar 2012e.pdf

[37] “Hitachi Annual Report 2012," 2012. http://www.hitachi.com/IR-e/library/annual/2012/ar2012e. pdf

[38] S. Desmet, R. van Dierdonck and B. van Looy, "Servitization: Or Why Services Management Is Relevant for Manufacturing Environments," Services Management: An Integrated Approach, Pearson Education, Harlow, 2003, pp. 40-51.

[39] C. Windahl and N. Lakemond, "Developing Integrated Solutions: The Importance or Relationships within the Network," Industrial Marketing Management, Vol. 35, No. 7, 2006, pp. 806-818. doi:10.1016/j.indmarman.2006.05.010

[40] J. Merdith, "Building Operations Management Theory through Case and Field Research," Journal of Operations Management, Vol. 16, No. 4, 1998, pp. 441-454. doi:10.1016/S0272-6963(98)00023-0

[41] H. P. Lu and J. Y. Wang, "The Relationship between Management Style, User Participation, and System Success over MIS Growth Stages," Information \& Management, Vol. 32, No. 3, 1997, pp. 203-213. doi:10.1016/S0378-7206(97)00021-9 